\title{
Breeding Management Practices and Reproductive Parameters of Ponies Reared by Bakarwal Population of Jammu and Kashmir
}

\author{
Nazish Rizwan Kirmani*, M. T. Banday and M. A. Pal \\ Division of Livestock Production and Management, \\ Faculty of Veterinary Sciences and Animal Husbandry, Shuhama-190006, \\ Sher-e-Kashmir University of Agricultural sciences and Technology of Kashmir, \\ Srinagar $(J \& K)$, India \\ *Corresponding author
}

\section{Keywords}

Bakarwals,

Breeding, Estrous, Mare, Reproduction

\section{Article Info}

Accepted:

17 June 2020

Available Online:

10 July 2020

\begin{abstract}
A B S T R A C T
Bakarwals, forming the socio economically backward section of Jammu and Kashmir, rear equine species such as ponies apart from sheep and goat for their livelihood. The lack of education and awareness among this section of society has led to poor understanding of managemental practices, healthcare etc. The literature available about reproductive characteristics and breeding management practices of these indigenous ponies of Jammu and Kashmir is not significant and hence this study was undertaken to acquire reliable, well documented information about the reproductive characteristics and breeding practices. To achieve the said objective a survey was conducted in Pahalgam and Sonmarg region of Kashmir, where a total of 200 respondents were randomly selected. The significant results were obtained from the data collected by using statistical tools. Natural breeding was found to be the only method of breeding practiced and quality of horse used for breeding was non-descriptive. The data also revealed that Heat detection and pregnancy diagnosis were not done. Moreover it was noted that only $26.31 \%$ of the respondents opted for treatment of anestrus/repeaters. The average age at first estrus, oestrous cycle duration, estrus duration, age at first foaling, foaling interval and gestation period was found to be 18.68 months, 21.84days, 165.89 hours, 37.63 months, 13.89months and 337 days respectively.
\end{abstract}

\section{Introduction}

Equines are mainly used as working animals, often carrying out tasks in harsh environmental conditions. They support people's livelihood in a wide range of sectors including agriculture, construction, tourism, mining and public transport. It is estimated that these animals help approximately 600 million people usually belonging to poor and marginalized communities (MacKenna, 2007). The total population of Horses and Ponies in India is 3.4 Lakhs, out of which is 0.63 lakhs are in Jammu and Kashmir, which is on second rank after Uttar Pradesh with population of 0.76lakhs (Anonymous, 2019). Livestock rearing forms core economic activity of Gujjar and Bakarwals, the third 
largest ethnic group of Jammu and Kashmir. Bakarwals belong to socially and economically backward sections of society and they have adopted sheep and goat rearing as their primary occupation. Apart from rearing sheep and goat they also rear few cattle and equine species like horse, ponies, donkeys etc. Due to widespread poverty and illiteracy among these pastoralists there is lack of understanding regarding managemental practices, healthcare etc. This remains a big hurdle in development of this sector. The reproductive characteristics and breeding management practices of indigenous horses of Jammu and Kashmir, reared by pastoralists have not been extensively studied, documented and reported. Going through the literature no reliable information was available concerning the reproductive parameters of these animals. Hence, documentation of the above mentioned parameters and practices was initiated for gathering reliable information for future reference.

\section{Materials and Methods}

The research survey was conducted in Pahalgam and Sonmarg falling under district Anantnag and Ganderbal of Kashmir, respectively. The regions were considered for survey as migratory pastoralist (Bakarwals) move to these regions during yearly migration owing to presence of highland pastures. A survey was conducted in order to gather information regarding breeding management practices followed by pastoralists (Bakarwals) and information regarding various reproductive parameters was collected from them. For sampling procedure Bakarwals were selected without any distinction on the basis of the flock size and the number of equines maintained by them. The grab sampling technique was followed in selecting 200 Bakarwals and the data was collected from such accidently selected respondents out of which 80 respondents were encountered in Pahalgam and 120 in Sonmarg. The information gathered from the selected pastoralists suggested the presence of 57 female animals among the surveyed lot. Being pastoralist's population, these respondents belonged to different districts of Jammu and Kashmir, and hence to achieve proper variation results were divided on the basis of region. Information derived from the respondents was collected by a pre designed interview schedule. Results were calculated by using simple technique of average and percentage. Percentages of various parameters under study were taken from each region and to arrive at an overall figure. Apart from the above statistical tools, Students t test was used in reproductive parameters.

\section{Results and Discussion}

\section{Breeding management}

The results of the survey on breeding practices and management have been presented in Table 1. The results indicated that only natural method of breeding is prevalent both Kashmir and Jammu region. The respondents were found to have minimal knowledge about A.I technique. These findings were similar to that of Singh et al., (2009) who reported that majority of equine rearer's preferred natural method of mating. However, Langlois (1977) observed that AI has number of advantages than natural mating, including disease control and easy semen transportation from one stud farm to another, but it has become increasingly obvious that to be successful with AI on large scale greater care should be put in action in semen evaluation and handling. The nonavailability of veterinary and A.I facilities have been noted to be the cause behind the non-implementation of A.I by equine rearers of both regions covered under the present study. Difficulty in performing A.I in equines, 
poor know how and lack of interest regarding this technique along with extensive system of rearing make it strenuous for equine rearers to opt for A.I. However these findings were contrary to results of Pal and Legha (2008), who reported that Equine owners showed keen interest in getting their mares artificially inseminated with superior frozen semen of donkeys for production of high-quality mules. This might be due progressive nature of equine rearers. In the present study it has been noted that only non- descript horse was used for breeding purpose and no modern veterinary procedures were used for detection of heat and diagnosis of pregnancy. However with respect to treatment of anestrus/repeaters overall only $26.31 \%$ opted for the treatment while as $73.68 \%$ did not. Among $26.31 \%$ of the respondents who opted for the treatment for anestrous, $15.78 \%$ consulted a veterinarian and the remaining $10.52 \%$ visited a traditional practioner. Similar results have been reported earlier by Singh et al., (2009) who reported that equine rearers did not prefer pregnancy diagnosis and treatment of repeaters by veterinarians. The results recorded in the present study can be attributed to the illiterate nature of population. The pastoralists' equine rearers go by the traditional methods and this mindset may be due to a number of factors like lack of knowledge regarding breeding management, lack of awareness regarding veterinary services or lack of facilities at veterinary centers, or due to reluctance of pastoralists towards veterinary care.

Lastly, regarding the segregation of mare before foaling, it was seen that $50.87 \%$ of equine rearers did not segregate mare before foaling while as $49.12 \%$ did practice segregation. Region wise comparison indicated that $57.14 \%$ segregated mare before foaling and $42.85 \%$ didn't in Kashmir region while as in Jammu region $46.51 \%$ segregated mare before foaling while as $53.48 \%$ didn't practice segregation.

\section{Reproductive parameters of Ponies}

The result of the survey on reproductive parameters of ponies is presented in table2.

\section{Age at first estrus}

The mean $( \pm \mathrm{SE})$ was noted to be $18.78 \pm 0.40$ months in Kashmir region and $18.65 \pm 0.16$ months in Jammu region respectively. These results are contrary to the findings of Valera et al., (2000), who reported that the age at first heat was recorded at 12.3 months in Lusitano native thoroughbred. The reasons for late heat may be the poor nutritional status of animals and lack of organised sector of equines in Jammu and Kashmir.

\section{Oestrus cycle duration}

Under the present study it has been found that the mean $( \pm \mathrm{SE})$ Oestrus cycle duration was21.42 \pm 0.25 days in Kashmir and $21.97 \pm 0.11$ days in Jammu region. Talluri et al., (2015) reported that Zanskari mares maintained at Equine Production Campus, Bikaner, had a mean Oestruscycle duration of $17.58 \pm 0.56$ days which is slightly lower than that indicated in the present study. The earlier reports of Andrews and McKenzie (1941) and Hafez and Hafez (2000) suggested that the average length of Oestrus cycle in exotic horses was 21 days, which is in trend with the results of present study.

\section{Estrus duration}

Mean $( \pm \mathrm{SE})$ of Estrus duration was noted to be $171.42 \pm 9.02$ hours in Kashmir region and $164.09 \pm 4.98$ hours in Jammu region. Similar results have been reported earlier by Talluri et $a l .$, (2015) who suggested an average duration of estrus in zanskari mares as 5.76 \pm 1.02 days with the range of 3-9 days. While as Daels et al., (1991) and Allen (1978) reported that the duration of estrus in exotic horses was 5-6 and 3-10 days, respectively. 
Table.1 Breeding management

\begin{tabular}{|c|c|c|c|c|}
\hline \multirow[t]{2}{*}{ Parameter } & \multirow[t]{2}{*}{ Category } & \multicolumn{2}{|c|}{ Region } & \multirow[t]{2}{*}{ Total $(\mathrm{N}=57)$} \\
\hline & & Kashmir $(n=14)$ & $\begin{array}{c}\text { Jammu } \\
(n=43)\end{array}$ & \\
\hline \multirow[t]{2}{*}{ Method of breeding } & Natural & $\begin{array}{c}14 \\
(100)\end{array}$ & $\begin{array}{c}43 \\
(100)\end{array}$ & $\begin{array}{c}57 \\
(100)\end{array}$ \\
\hline & A.I & \multicolumn{3}{|c|}{ Nil } \\
\hline \multirow[t]{2}{*}{ Quality of breeding horse } & Thorough bred & \multicolumn{3}{|c|}{ Nil } \\
\hline & Non descriptive & $\begin{array}{c}14 \\
(100)\end{array}$ & $\begin{array}{c}43 \\
(100)\end{array}$ & $\begin{array}{c}57 \\
(100)\end{array}$ \\
\hline \multirow[t]{2}{*}{ Heat detection } & Yes & \multicolumn{3}{|c|}{ Nil } \\
\hline & No & $\begin{array}{c}14 \\
(100)\end{array}$ & $\begin{array}{c}43 \\
(100)\end{array}$ & $\begin{array}{c}57 \\
(100)\end{array}$ \\
\hline \multirow[t]{2}{*}{ Pregnancy diagnosis } & Yes & \multicolumn{3}{|c|}{ Nil } \\
\hline & No & $\begin{array}{c}14 \\
(100)\end{array}$ & $\begin{array}{c}43 \\
(100)\end{array}$ & $\begin{array}{c}57 \\
(100)\end{array}$ \\
\hline \multirow[t]{2}{*}{$\begin{array}{c}\text { Treatment of anestrous } \\
\text { /repeaters }\end{array}$} & Yes & $\begin{array}{c}4 \\
(28.57)\end{array}$ & $\begin{array}{c}11 \\
(25.58)\end{array}$ & $\begin{array}{c}15 \\
(26.31)\end{array}$ \\
\hline & No & $\begin{array}{c}10 \\
(71.42)\end{array}$ & $\begin{array}{c}32 \\
(74.41)\end{array}$ & $\begin{array}{c}42 \\
(73.68)\end{array}$ \\
\hline \multirow[t]{2}{*}{$\begin{array}{l}\text { If treated then who is } \\
\text { consulted }\end{array}$} & Veterinary doctor & $\begin{array}{c}2 \\
(14.28)\end{array}$ & $\begin{array}{c}7 \\
(16.27)\end{array}$ & $\begin{array}{c}9 \\
(15.78)\end{array}$ \\
\hline & $\begin{array}{l}\text { Traditional } \\
\text { practioner }\end{array}$ & $\begin{array}{c}2 \\
(14.28)\end{array}$ & $\begin{array}{c}4 \\
(9.30)\end{array}$ & $\begin{array}{c}6 \\
(10.52)\end{array}$ \\
\hline \multirow[t]{2}{*}{$\begin{array}{l}\text { Segregate mare before } \\
\text { foaling }\end{array}$} & Yes & $\begin{array}{c}8 \\
(57.14) \\
\end{array}$ & $\begin{array}{c}20 \\
(46.51)\end{array}$ & $\begin{array}{c}28 \\
(49.12)\end{array}$ \\
\hline & No & $\begin{array}{c}6 \\
(42.85)\end{array}$ & $\begin{array}{c}23 \\
(53.48)\end{array}$ & $\begin{array}{c}29 \\
(50.87)\end{array}$ \\
\hline
\end{tabular}

Figures in parenthesis indicate percentage

Table.2 Reproductive parameters of ponies

\begin{tabular}{|c|c|c|c|c|c|}
\hline \multicolumn{6}{|c|}{ Reproductive parameters of mares } \\
\hline \multirow{2}{*}{\multicolumn{2}{|c|}{ Parameters }} & \multicolumn{2}{|c|}{ Region } & P value & Total \\
\hline & & $\begin{array}{c}\text { Kashmir } \\
(n=14)\end{array}$ & $\begin{array}{c}\text { Jammu } \\
(n=43)\end{array}$ & & $(\mathrm{N}=57)$ \\
\hline \multicolumn{2}{|l|}{ Age at first oestrus (months) } & $18.78 \pm 0.40$ & $18.65 \pm 0.16$ & 0.763 & $18.68 \pm 0.15$ \\
\hline \multicolumn{2}{|l|}{ Oestrus cycle duration (days) } & $21.42 \pm 0.25$ & $21.97 \pm 0.11$ & 0.06 & $21.84 \pm 0.11$ \\
\hline \multicolumn{2}{|l|}{ Oestrus duration (hours) } & $171.42 \pm 9.02$ & $164.09 \pm 4.98$ & 0.48 & $165.89 \pm 4.34$ \\
\hline \multicolumn{2}{|l|}{ Age at first foaling (months) } & $37.85 \pm 0.90$ & $37.55 \pm 0.43$ & 0.768 & $37.63 \pm 0.39$ \\
\hline \multicolumn{2}{|l|}{ Foaling interval(months) } & $15.21 \pm 0.42$ & $13.46 \pm 0.17$ & $0.001 *$ & $13.89 \pm 0.19$ \\
\hline \multicolumn{2}{|c|}{ Gestation period (days) } & $337.85 \pm 0.51$ & $337.72 \pm 0.72$ & 0.936 & $337.75 \pm 0.65$ \\
\hline \multicolumn{4}{|c|}{ Reproductive parameters of stallion } & & \\
\hline & \multicolumn{2}{|l|}{$\mathrm{n}=27$} & $\mathrm{n}=116$ & & $\mathrm{~N}=143$ \\
\hline $\begin{array}{l}\text { Age at puberty in males } \\
\text { (months) }\end{array}$ & \multicolumn{2}{|c|}{$23.25 \pm 0.68$} & $23.04 \pm 0.36$ & 0.97 & $23.08 \pm 0.35$ \\
\hline
\end{tabular}

Figures in parenthesis indicate percentage

Statistical tests reflect the results between regions and * (asterisk) indicate significant difference at 5 percent level of significance 


\section{Age at first foaling}

The mean $( \pm \mathrm{SE})$ age at first foaling was noted to be $37.85 \pm 0.90$ months in Kashmir region and $37.55 \pm 0.43$ months in Jammu region. However, Pundir (2001) observed that the average age at first foaling was 1297 days (42.6 months) in Spiti horses which is slightly more than the present study.

\section{Foaling interval}

The present study indicated that the mean $( \pm$ SE) Foaling interval in Kashmir region was15.21 \pm 0.42 months while as in Jammu region it was found to be $13.46 \pm 0.17$ months. However significant difference at $(\mathrm{p}<0.05)$ was observed in both regions. These results are similar to the earlier findings of Tavier $e t$ al., (2007) who reported foaling interval of 490 days (16months) in thoroughbred in Brazil. However, Pundir (2001) reported foaling interval of 516 days (16.9 month) in Spitihorses, which is slightly higher than the present study.

\section{Gestation period}

The Mean $( \pm$ SE) for gestation period was observed to be $337.85 \pm 0.51$ days in Kashmir and $337.72 \pm 0.72$ days in Jammu region. Similar results were recorded by Bos and Mey, 1980 who reported that the average length of gestation period in mares ranges from 330 to 340 days. Moreover, Morel et al., (2002) suggested that gestation period of pony breeds ranged between 320 and 335 days. Singh et al., (2002) reported the mean gestation length of $338.3 \pm 3$ days, and $334 \pm 5$ in field and 331 \pm 1.9 days among farm reared Marwari and Kathiawari mares respectively. Pundir (2001) reported average gestation length of 333 days in Spiti horses which is similar to findings among mares of Jammu and Kashmir under present study. These finding are also in trend with our results. Gestation length in the mare has been found to be influenced by maternal size, fetal genotype and the stage of the breeding season when conception occurs (Jainudeen and Hafez, 1993). Various studies on gestation duration in relation to foal gender emphasized prolonged gestation in colts compared to fillies (Bos and Mey, 1980, Morel et al., 2002, Perez et al., 2003, Taveira and Mota, 2007).

\section{Age at puberty}

Regarding males mean $( \pm \mathrm{SE})$ for age at puberty was $23.25 \pm 0.68$ months in Kashmir region and 23.04 \pm 0.36 months in Jammu region, respectively. Naden et al., (1990) reported age of puberty Quarter horses in range of 14 to 24 months which is in trend with our findings. However contrary to above results Skinner and Bowen, 1968 reported puberty in welsh ponies to be 12-15 months.

In conclusion, study revealed basic information on breeding management practices and reproductive characteristics of ponies reared by Bakarwals in Jammu and Kashmir. However extensive literature is not available in this context, despite Jammu and Kashmir being ranked number $2^{\text {nd }}$ in Horses and Pony population. The lack of scientific data paves way for in-depth study in this field. Government and research institutes should come forward and make a joint effort to educate pastoralist regarding breeding management practices. They should further focus on making the population aware about modern veterinary practices such as A.I. Moreover efforts should be to make veterinary centres easily accessible to them.

\section{References}

Allen, W.R. 1978. Control of Ovulation and Oestrus in the Mare. In: Crighton, D.P., Haynes, H.B., Foxcroft, G.R and Lamming, G.E. (edu) Control of ovulation. Butterwoths, London. pp. 453-68. 
Andrews,F.N.and

McKenzie,F.F.1941.Estrus,Ovulation and Related Phenomena in the Mare. Missouri Agricultural Research Bulletin, 329.

Anonymous.2019. 20 $0^{\text {th }}$ Livestock Census, Directorate of Economics and Statistics, and Animal Husbandry Statistics Division, Department of Animal Husbandry, Dairying and Fisheries, Ministry of Agriculture, Govt. of India.

Bos, H. and Mey, G.J.W. 1980. Length of gestation period of horses and ponies belonging to different breeds. Livestock Production Science, 7(2): 181-87.

Daels,P.F., Hughes, J.P. and Stabenfeldt, G.H. 1991.Reproduction in horses. Reproduction in Domestic Animals.4th edn. (Ed.) Cupps P T. Academic press, New York.

Hafez, E. S. E. and B. Hafez. 2000. Horses. In: Reproduction in Farm Animals (Ed. E. S. E. Hafez, B. Hafez, Lippincott Williams and Wilkins). 7th ed. Philadelphia. pp. 192-217.

Jainudeen, M. R. and E. S. E. Hafez. 1993. Gestation, prenatal physiology, and parturition. In: Reproduction in Farm Animals (Ed. E. S. E. Hafez. Lea and Febiger).6th ed. Philadelphia. pp. 213-236.

Langlois, B. 1977.Effects of Stallion on fertility in the breeding of warm blood horses. Annnales de Zootechnie, 26:329-344.

MacKenna. 2007. Bearing a Heavy Burden, The Brooke, London, available at http://www.thebrooke.org/_data/assets/pdf_fi le/0010/50968/BROOKE_heavy_burden.pdf.

Naden, J., Squires, E.L., Nett, T.M. and Amann, R.P. 1990. Effect of maternal treatment with altrenogest on pituitary response to exogenous $\mathrm{GnRH}$ in pubertal stallions. Journal of Reproduction and Fertlity, 88(1):177-183.

Morel, D., Newcombe, J.R. and Holland, S.J. 2002.Factors affecting gestation length in the thoroughbred mare. Animal Reproduction
Science, 74 (3/4):175-85.

Pal, Y. and Legha, R. A. 2008.A study on socioeconomic of mule producers and management practices of mule in rural areas. Indian Journal of Animal Sciences, 78(11):1281-1284.

Perez,C.C., Rodríguez, I., Mota, J., Dorado, J., Hidalgo, M. and Felipe,M. 2003. Gestation length in Carthusian Spanishbred mares. Livestock Production Science, 82(2/3): 18187.

Pundir, R.K. 2001. Physical and morphological characteristics of spitihorses. Indian Journal of Animal Sciences, 71(4):381-382.

Skinner,J.D and Bowen,J.1968. Puberty in the Welsh Stallion.Journal of Reproduction and Fertlity, 16(1):133-135.

Singh, M. K., Yadav, M. P. and Mehta, N. T. 2002. Breed characteristics of Marwari and Kathiawari horses. Indian Journal of Animal Science, 72(4): 319-323.

Singh, B.P., Sharma, M.C. and Tiwari, R. 2009. Feeding resources and management among poor livestock keeper: A field study in linkage villages. The Indian Journal of Animal Sciences, 79 (12): 1263-1264.

Talluri, T.R., Ravi, S K., Singh, J., Legha, R.A., Pal, Y. Gupta, A. K., Singh., R. K. and Tripathi, B.N. 2015. Some reproductive parameters of Zanskari mares reared in an organized farm under tropical climate. Indian Journal of Animal Sciences, 86 (2): 163-167.

Taveira, R.Z. and Mota, M.D.S. 2007. Genetic and quantitative evaluation of breeding traits in thoroughbred mares. Revista Electronica de Veterinaria, 8(5):1-11.

Valera, M., Esteves, L., Oom, M. M. and Molina, A. 2000. The Lusitano Native Thoroughbred: a genetic study of the important reproductive parameters in plans for conservation and improvement. Journal of Archivosde Zootecnia, 49(185/186): 147-156.

\section{How to cite this article:}

Nazish Rizwan Kirmani, M. T. Banday and Pal, M. A. 2020. Breeding Management Practices and Reproductive Parameters of Ponies Reared by Bakarwal Population of Jammu and Kashmir. Int.J.Curr.Microbiol.App.Sci. 9(07): 1971-1976.

doi: https://doi.org/10.20546/ijcmas.2020.907.225 